\title{
Werktijden en ouder-kindtijd in de middag en avond
}

\author{
Melissa Verhoef \& Anne Roeters*
}

Deze studie richt zich op de samenhang tussen de werktijden van ouders en ouder-kindtijd. We maken niet alleen onderscheid tussen het aantal werkuren en het werkschema van ouders maar ook tussen ouder-kindtijd in de middag en in de avond. In onze hypothesen staan de beschikbaarheid van kinderen en ouders centraal. Onze analyses zijn gebaseerd op 694 ouders met jonge kinderen uit het Nederlandse Tijdsbestedingsonderzoek van 2006 en 2011. Resultaten laten zien dat de tijd die ouders met's middags met hun kinderen doorbrengen vooral samenhangt met het aantal uren dat zij werken, terwijl voor ouder-kindtijd in de avond het werkschema van ouders juist van belang is. Meerdere mogelijkheden voor vervolgonderzoek worden aangedragen, zoals een vergelijking tussen week- en weekenddagen en een focus op de kwaliteit van ouder-kindtijd.

\section{Introductie}

Het idee dat betaald werk moeilijk combineerbaar is met de zorg voor kinderen is hardnekkig, zowel in de wetenschappelijke literatuur als in het maatschappelijk debat (Bianchi, Robinson \& Milkie, 2006; Hsin \& Felfe, 2014; Roeters, Van der Lippe \& Kluwer, 2010). Deze discussie richt zich met name op de mogelijke negatieve invloed van werktijden van ouders, waarbij er zowel aandacht is voor het aantal werkuren, als voor het moment waarop gewerkt wordt (Bianchi, 2000; Bianchi et al., 2006; Monna \& Gauthier, 2008; Nock \& Kingston, 1988). In Nederland werkt ongeveer één derde van de ouders 's avonds, 's nachts of in het weekend (Presser, Gornick \& Parashar, 2008; Verhoef, Tammelin, May, Rönka \& Roeters, 2015) en aangezien de hoeveelheid en aard van de tijd die hun ouders met kinderen doorbrengen bepalend is voor het welzijn van kinderen (e.g., Zick, Bryant \& Osterbacka, 2001; Milkie, Mattingly, Nomaguchi, Bianchi \& Robinson, 2004), is het belangrijk om te onderzoeken of werk buiten kantoortijden inderdaad ten koste gaat van ouder-kindtijd.

Eerder onderzoek naar het verband tussen werktijden en ouder-kindtijd heeft enkel gekeken naar de totale tijd die ouders met hun kinderen doorbrengen. Hierdoor is de centrale aanname dat werk buiten kantoortijden ten koste gaat van gezinstijd in de avonden en weekenden onvoldoende empirisch getest. Ouders kunnen de gemiste tijd immers op andere momenten compenseren en bijvoorbeeld makkelijk's middags met hun kind naar de speeltuin gaan. Hoewel dit punt eerder gemaakt is (e.g., Connelly \& Kimmel, 2007; Heymann \& Earle, 2001), kennen wij geen studies die een onderscheid tussen ouder-kindtijd in de middag en

* Melissa Verhoef en Anne Roeters zijn werkzaam bij Universiteit Utrecht, faculteit Sociale Wetenschappen, afdeling Sociologie. E-mail: m.verhoef@uu.nl. 
avond maken. Deze studie vult dit gat in de literatuur op door te onderzoeken hoe de werktijden van ouders samenhangen met ouder-kind activiteiten in de avond en middag. We onderzoeken twee dimensies van de 'werktijden' van ouders: het aantal werkuren (werken ze fulltime of parttime?) en het werkschema (werken ze binnen of buiten kantoortijden?). De combinatie van beide dimensies bepaalt immers de mogelijkheden en restricties van ouder-kindtijd (Täht \& Mills, 2012). Door een onderscheid te maken tussen de middag en avond kunnen we de aanname toetsen dat ouders die buiten kantooruren werken hun kinderen 's avonds minder en 's middags vaker zien, maar dit onderscheid is om een tweede reden interessant. De omstandigheden voor ouder-kindtijd zijn namelijk anders in de middag en avond, waardoor de samenhang met werkuren wellicht ook zal verschillen.

Middagen worden gekenmerkt door beperkte beschikbaarheid van kinderen. Kinderen gaan namelijk naar school en/of (naschoolse) opvang, spelen bij vriendjes en vriendinnetjes en ondernemen naschoolse activiteiten (Bianchi, 2000) en de meeste van deze activiteiten vinden overdag plaats. Daarnaast is het waarschijnlijk dat ouders overdag zelf ook beperkt beschikbaar zijn, ook als ze parttime of buiten kantoortijden werken. Mensen moeten boodschappen doen, mantelzorgen en participeren in het maatschappelijk middenveld. Deze activiteiten vinden vaak overdag plaats, binnen de openingstijden van winkels, praktijken en maatschappelijke instellingen. Deze brede participatie wordt met de opkomst van de participatiemaatschappij steeds belangrijker en zal ouder-kindtijd mogelijk in de weg zitten. In de avonduren, daarentegen, zullen kinderen vaker thuis zijn en zijn er minder activiteiten die met ouder-kindtijd 'concurreren'. We verwachten daarom dat werktijden ouder-kindtijd het meest beperken als ouders fulltime en buiten kantoortijden werken.

Onze analyses zijn gebaseerd op het Nederlandse Tijdsbestedingsonderzoek (TBO) van 2006 en 2011 van het Sociaal en Cultureel Planbureau (SCP) en Centraal Bureau voor de Statistiek (CBS). Deze data bevatten dagboekgegevens over een gehele week, waarbij we alleen ouders analyseren die aangeven in deze dagboekweek te hebben gewerkt. In onze analyses contrasteren we het effect van werktijden op ouder-kindtijd in de middag (14.00-18.00 uur) en avond (18:00-22:00 uur) van doordeweekse dagen. Er is voor gekozen om de ochtend niet mee te nemen omdat veel kinderen dan op school zitten. Ook jonge kinderen zijn beperkt beschikbaar: een substantieel deel gaat naar formele kinderopvang (Coyette, Fiasse, Johansson, Montaigne \& Strandell, 2015), waar kinderen doorgaans vroeg in de ochtend gebracht moeten worden (Cloïn, Schols, Van den Broek \& Koutamanis, 2010). Om de breedte van de analyses af te bakenen hebben we ervoor gekozen om ons op doordeweekse dagen te richten. Dit is niet ongebruikelijk in de literatuur (e.g., Wright, Raley \& Bianchi, 2008).

Tijdbestedingsonderzoek heeft verschillende voordelen ten opzichte van standaard vragenlijsten. Omdat ouders over precieze dagen rapporteren zijn de meetfouten kleiner en is er minder sprake van sociale wenselijkheid (Kan \& Pudney, 2008). Doordat we weten wanneer mensen aan welke activiteit deelnamen, kun- 
nen we de timing van zowel de ouder-kindtijd als de werkuren in kaart brengen. In standaardvragenlijstonderzoek wordt respondenten vaak gevraagd zelf hun werkschema te typeren (wat foutgevoelig is) en wordt de totale tijd met kinderen geschat.

\section{Werk buiten kantoortijden en tijd met kinderen}

\section{Eerder onderzoek}

Het idee dat westerse samenlevingen zich ontwikkelen tot '24/7'-maatschappijen is voor een aantal studies de aanleiding geweest om het verband tussen werk buiten kantoortijden, tijd met kinderen, en het welzijn van kinderen te onderzoeken (voor een review, zie Li et al., 2014). Hoewel een overkoepelend theoretisch kader ontbreekt, kunnen in het theoretische debat twee visies worden onderscheiden. De eerste groep onderzoekers, die we als 'de pessimisten' zullen kenmerken, stelt dat werk buiten kantoortijden het welzijn van ouders en kinderen schaadt (La Valle, Arthur, Millward, Scott \& Clayden, 2002; Strazdins, Korda, Lim, Broom \& D'Souza, 2004). Er wordt geredeneerd dat de werkuren van deze ouders de gezinstijd beperken omdat deze ouders vaker in de avonden en weekenden werken. Ook wordt verondersteld dat de mentale en fysieke belasting ten koste gaan van tijd met kinderen. Zo zullen ouders die 's nachts werken overdag minder energie hebben om activiteiten met hun kinderen te ondernemen. Deze verwachtingen worden ondersteund door de bevindingen dat werk tijdens het weekend gepaard gaat met minder ouder-kindtijd (Presser, 2003) en dat mensen die buiten kantoortijden werken vaker depressies en burn-outverschijnselen rapporteren (Jamal, 2004; Perry-Jenkins, Goldberg, Pierce \& Sayer, 2007) en een lager welzijn ervaren (Schulz, Cowan, Cowan \& Brennan, 2004).

De tweede groep, 'de optimisten', stelt dat werk buiten kantoortijden gezinnen juist in staat stelt om meer tijd met hun kinderen door te brengen (Presser, 2003; Täht \& Mills, 2012). Immers, als de ene ouder thuis kan zijn terwijl de andere ouder werkt, maximaliseren ouders de totale zorgtijd voor hun kinderen en hoeven kinderen niet of minder naar de opvang te worden gebracht. Ook stellen onderzoekers als Nock en Kingston (1988) dat vaders meer voor hun kinderen zorgen als de afwezigheid van de moeder hen daartoe 'dwingt'. Hier bovenop kan er sprake zijn van een selectie-effect: betrokken ouders die veel tijd met hun kinderen doorbrengen zullen vaker buiten kantooruren werken. In lijn met de optimistische visie, vinden Wight et al. (2008) en Täht en Mills (2012) dat ouders die buiten kantoortijden werken vaker tijd met hun kinderen doorbrengen. Verder laat de studie van Han (2004) zien dat met name vaders meer voor hun kinderen zorgen als zij zelf, of beide ouders, buiten kantoortijden werken.

Hoewel het onderzoek van de optimisten en pessimisten voor een groot deel in de VS is gedaan heeft Täht (2011) laten zien dat werkschema's van ouders ook in Nederland een rol spelen. De schadelijke effecten zijn weliswaar kleiner dan in de VS, maar zijn wel degelijk aanwezig. 


\section{Verwachtingen}

\section{Basishypothese}

$\mathrm{Bij}$ het formuleren van hypothesen over de samenhang tussen de werktijden van ouders en de tijd met kinderen in de middag en avond, starten we bij de rol van werkschema's van ouders en nemen we de bestaande literatuur als uitgangspunt. Onze basishypothese is gebaseerd op de aanname die zowel bij de pessimisten als de optimisten centraal staat. Vanuit de simpele gedachte dat tijd een schaars goed is, stellen beiden namelijk het volgende:

Ouders die buiten kantoortijden werken brengen 's middags meer tijd met hun kinderen door dan ouders die binnen kantoortijden werken (Basishypothese 1a)

Ouders die binnen kantoortijden werken brengen 's avonds meer tijd met hun kinderen door dan ouders die buiten kantoortijden werken (Basishypothese 1b)

\section{De rol van beschikbaarheid}

In de volgende stap nuanceren we de (vrij simpele) verwachting van de basishypothesen door de rol van de beschikbaarheid van kinderen en ouders mee te nemen. In 2000 stelde Bianchi al dat het meeste werk-familieonderzoek gebaseerd is op de onrealistische aanname dat kinderen altijd beschikbaar zijn als ouders tijd voor hen hebben. Kinderen besteden echter veel tijd op school, in clubjes, buiten en bij andere kinderen thuis (Hofferth \& Sandberg, 2001). In de meeste gevallen zullen de naschoolse activiteiten direct na schooltijd plaatsvinden. Om deze reden verwachten we dat ouders die 's middags thuis zijn omdat ze niet hoeven te werken, slechts een deel van deze tijd daadwerkelijk met hun kinderen doorbrengen. In de avond zijn de meeste kinderen thuis en daarom zullen ouders die dan niet hoeven te werken meer tijd met hun kinderen door kunnen brengen. De basishypothese kan dus worden genuanceerd door de sterkte van de effecten te specificeren. Gebaseerd op de beschikbaarheid van kinderen verwachten we het volgende:

De positieve samenhang van werk buiten kantoortijden met ouder-kindtijd in de middag is zwakker dan de positieve samenhang van werk binnen kantoortijden met ouder-kindtijd in de avond (Hypothese 2)

Ook de beschikbaarheid van ouders kan van belang zijn. De meeste onderzoeken naar de combinatie van arbeid en zorg laten buiten beschouwing dat ouders niet al hun tijd tussen hun werk en de zorg voor kinderen verdelen. Ouders besteden ook tijd aan hobby's, het huishouden, cursussen, informele zorg aan niet-huishoudleden en vrijwilligerswerk (Cloïn et al., 2013). Al deze activiteiten kunnen het voor ouders moeilijk maken om buiten werktijd tijd met hun kinderen door te brengen. We verwachten dat deze 'verdringing' sterker zal zijn als ouders fulltime werken. Deze ouders hebben namelijk minder tijd en speelruimte om activiteiten als huishoudelijke arbeid af te stemmen op de beschikbaarheid van kinderen. Om 
deze reden formuleren we in de volgende sectie verwachtingen over de combinatie van werkuren en werkschema's.

\section{De combinatie van werkuren en werkschema's}

\section{- Ouder-kindtijd in de middag}

We verwachten dat ouders met een fulltime baan buiten kantoortijden 's middags minder tijd met hun kinderen door kunnen brengen dan ouders met een parttime baan buiten kantoortijden. Bij de laatste groep is er minder sprake van verdringing en hebben ouders meer mogelijkheden om andere activiteiten om de beschikbaarheid van kinderen heen te plooien. De fulltime werkende ouders hebben deze vrijheid minder. Daarbij is het waarschijnlijk dat ouders met een fulltime baan buiten kantoortijden 's middags moe zijn en zelfs bij moeten slapen. Dus als we Basishypothese $1 \mathrm{a}$ als uitgangspunt nemen en differentiëren naar arbeidsduur, kan de volgende hypothese worden opgesteld voor ouders die buiten kantoortijden werken:

De positieve samenhang tussen werk buiten kantoortijden en ouder-kindtijd in de middag is sterker voor ouders met een parttime baan (Hypothese 3 )

Ook voor ouders die binnen kantoortijden werken kan Basishypothese 1a worden gespecificeerd. Vanzelfsprekend hebben ouders met een fulltime baan binnen kantoortijden de minste mogelijkheden om 's middags tijd met hun kinderen door te brengen. Hoewel telewerk en flexibele uren ouders in staat kunnen stellen om enigszins tijd met hun kinderen door te brengen, zijn zij doorgaans aan het werk. Ouders met een parttime baan zijn echter wel gedurende een deel van de week vrij in de middag. Voor ouders met werk binnen kantoortijden verwachten we dus:

De negatieve samenhang tussen werk binnen kantoortijden en ouder-kindtijd in de middag is zwakker voor ouders met een parttime baan (Hypothese 4)

\section{- Ouder-kindtijd in de avond}

Vervolgens kunnen er ook meer specifieke verwachtingen over ouder-kindtijd in de avond worden geformuleerd. We specificeren Basishypothese $1 \mathrm{~b}$ allereerst voor ouders met een baan buiten kantoortijden. De mogelijkheden om 's avonds tijd met kinderen door te brengen zullen het meest beperkt zijn voor ouders die fulltime werken. Deze groep ouders zal dan vaak moeten werken en op de vrije avonden vaker tijd aan andere activiteiten willen en moeten besteden. Ouders met een parttime baan buiten kantoortijden, daarentegen, zullen vaker een avond vrij hebben. We verwachten daarom het volgende:

De negatieve samenhang tussen werk buiten kantoortijden en ouder-kindtijd in de avond is zwakker voor ouders met een parttime baan (Hypothese 5)

Onze laatste hypothese heeft betrekking op de ouder-kindtijd in de avond van ouders met een baan binnen kantoortijden. Indien deze ouders een fulltime baan 
hebben, zullen zij de avonden vaak nodig hebben voor andere activiteiten, zoals sport en het doen van huishoudelijke taken. Ouders met een parttime baan binnen kantoortijden, daarentegen, kunnen deze activiteiten ook overdag doen en zijn daarom in de avonduren meer beschikbaar voor hun kinderen. Daarom verwachten we het volgende:

De positieve samenhang tussen werk binnen kantoortijden en ouder-kindtijd in de avond is sterker voor ouders met een parttime baan (Hypothese 6)

\section{Data en methoden}

\section{Data}

Om inzicht te krijgen in de tijdsbesteding van Nederlandse ouders hebben wij gebruikgemaakt van het Nederlandse Tijdsbestedingsonderzoek (TBO) 2006 en 2011. Het TBO is een tijdsbestedingsonderzoek dat iedere vijf jaar uitgevoerd wordt, sinds 2006 volgens de Europese richtlijnen (Kamphuis, Van den Dool, Van den Broek, Stoop, Adelaar \& De Haan, 2009). Dit houdt in dat er een steekproef wordt getrokken van de Nederlandssprekende bevolking van 10 jaar en ouder, die gevraagd wordt voor zeven aaneengesloten dagen een dagboek in te vullen met tijdsintervallen van tien minuten. Hierbij moet de respondent zowel hoofdactiviteiten als nevenactiviteiten rapporteren, evenals met wie en waar de activiteit plaatsvindt. Ter aanvulling op het dagboek wordt ook een telefonische basis- en slotvragenlijst afgenomen, om aanvullende informatie over de respondent te verkrijgen.

In 2006 zijn in totaal 3.041 mensen benaderd voor deelname aan het TBO, van wie uiteindelijk 1.875 zowel het dagboek hebben ingevuld als mee hebben gewerkt aan de basis- en slotvragenlijst. Dit komt neer op een respons van $62 \%$. Het afnemen van de vragenlijsten vond plaats tussen september 2005 en februari 2007; het invullen van de dagboeken is tussen januari en december 2006 gebeurd. In 2011 zijn in totaal 4.976 mensen benaderd voor deelname, waarvan er 2.005 volledig hebben meegewerkt aan de dataverzameling. De respons in 2011 ligt daarmee op 40\%. De dataverzameling voor het TBO 2011 vond plaats tussen maart 2011 en maart 2012.

De focus van dit artikel is op werkende ouders met kinderen. Om tot een voldoende grote steekproef te komen, hebben wij de datasets van het TBO 2006 en TBO 2011 gecombineerd, wat neerkomt op een totaal van 3.880 respondenten. Hiervan hebben wij allereerst alleen de respondenten geselecteerd met kinderen tussen de 0 en 11 jaar oud, waardoor 2.995 respondenten uitgesloten werden van onze steekproef. Vervolgens zijn de respondenten geselecteerd die in de dagboekweek betaalde arbeid hebben verricht, waardoor er 143 respondenten afvielen. Ten slotte vielen er nog 48 respondenten af die totaal geen ouder-kindtijd hadden gerapporteerd in hun dagboek. Dit heeft geleid tot een steekproef van 694 werkende ouders met jonge kinderen, die ofwel in 2006 ofwel in 2011 hebben deelgenomen aan het TBO. 


\section{Operationalisering}

De afhankelijke variabele, tijd met kinderen, is samengesteld aan de hand van het ingevulde dagboek van de respondenten. Hiervoor hebben wij gekeken naar tien verschillende kindgerelateerde activiteiten, zoals eten geven, naar bed brengen en voorlezen, spelen en praten met kind. Voor iedere respondent is per weekdag berekend hoeveel ouder-kindtijd hij/zij 's middags en 's avonds heeft gerapporteerd. Tijd met kinderen 's middags betreft de totale tijd die ouders op maandag tot en met vrijdag tussen 14 uur 's middags en 18 uur's avonds met hun kind doorbrengen; tijd met kinderen 's avonds betreft de totale tijd die ouders op maandag tot en met vrijdag tussen 18 uur's avonds en 22 uur's avonds met hun kind doorbrengen.

De variabele werk buiten kantoortijden is eveneens samengesteld aan de hand van de ingevulde dagboeken. Hiervoor is allereerst de totale arbeidsduur per weekdag berekend, omvat door acht werk-gerelateerde activiteiten zoals betaald werk op de werkplek, koffiepauzes en studie onder werktijd. Hierna is voor iedere weekdag berekend of de werkuren van de respondent binnen kantoortijden vallen, door gebruik te maken van de definitie van Presser (2003). Dit houdt in dat indien de meerderheid van de werkuren tussen 8 uur's ochtends en 16 uur's middags valt, de respondent gecategoriseerd wordt als werkend binnen kantoortijden, zo niet, dan als werkend buiten kantoortijden. Bijvoorbeeld, een respondent werkt acht uur per dag, van 13 tot 21 uur. Slechts drie uur van deze werkuren vallen tussen 8 en 16 uur, waardoor deze respondent in de categorie 'werk buiten kantoortijden' valt. Dit is voor iedere respondent berekend van maandag tot en met vrijdag, waarna vervolgens een dummyvariabele 'werk buiten kantoortijden' is gemaakt. Respondenten die één keer of vaker op weekdagen buiten kantoortijden hebben gewerkt, hebben hierbij waarde 1 gekregen; de waarde 0 betekent dat de respondent iedere weekdag binnen kantoortijden heeft gewerkt.

Om te bepalen of respondenten parttime werken, is gekeken naar de totale arbeidsduur per week. Indien dit aantal onder de 35 uur was, kregen respondenten waarde 1 op de dummyvariabele voor parttime werk; respondenten die 35 uur of meer hebben gewerkt, kregen waarde 0 .

Een aantal achtergrondkenmerken van de respondent zijn als controlevariabelen meegenomen in de analyses. Dit zijn het geslacht $(0=$ man, $1=$ vrouw $)$, het opleidingsniveau (variërend van 1 = basisonderwijs tot $4=$ hbo of hoger) en het aantal kinderen van de respondent en of de respondent een kind heeft tussen de 0 en 3 jaar oud $(0=$ nee, $1=j a)$. Onderzoek heeft namelijk laten zien dat vrouwen, hoger opgeleide ouders en ouders van jongere en meer kinderen meer tijd met hun kinderen doorbrengen (Monna \& Gauthier, 2008). Ten slotte hebben we, aangezien we data gebruiken uit twee verschillende jaartallen, een variabele gemaakt om hiermee rekening te houden $(0=$ TBO 2006, 1 = TBO 2011). We controleren voor het jaar waarin de data verzameld zijn om zo enigszins rekening te houden met periode-effecten zoals de economische crisis en de wijzigingen in de kinderopvangwetgeving (Portegijs, Cloïn \& Merens, 2014). 
Tabel 1 Beschrijvende statistieken voor variabelen betreffende ouderkindtijd, de werktijden van ouders en de controlevariabelen $(N=694)$

\begin{tabular}{|c|c|c|c|}
\hline Variabelen & M & SD & Bereik \\
\hline \multicolumn{4}{|l|}{ Afhankelijke variabelen } \\
\hline Tijd met kinderen 's middags & $\mathrm{I}, 07$ & $\mathrm{I}, 27$ & $0-8,50$ \\
\hline Tijd met kinderen 's avonds & 2,46 & 1,63 & $0-7,83$ \\
\hline \multicolumn{4}{|l|}{ Onafhankelijke variabelen } \\
\hline Werk buiten kantoortijden $(0=$ nee, $\mathrm{I}=\mathrm{ja})$ & 0,21 & 0,41 & $0-1$ \\
\hline Parttime werk $(0=$ nee, $\mathrm{I}=\mathrm{ja})$ & 0,74 & 0,44 & $0-1$ \\
\hline \multicolumn{4}{|l|}{ Controlevariabelen } \\
\hline Geslacht respondent $(0=$ man, $\mathrm{I}=$ vrouw $)$ & 0,55 & 0,50 & $0-1$ \\
\hline Opleidingsniveau respondent & 3,30 & 0,76 & $\mathrm{I}-4$ \\
\hline Aantal kinderen & 1,98 & 0,80 & $\mathrm{I}-4$ \\
\hline Kind tussen $0-3$ jaar $(0=$ nee, $\mathrm{I}=\mathrm{ja})$ & 0,47 & 0,50 & $0-1$ \\
\hline Jaar dataverzameling $(0=2006, \mathrm{I}=201 \mathrm{I})$ & 0,44 & 0,50 & $0-1$ \\
\hline
\end{tabular}

\section{Analysestrategie}

Voor de analyses hebben wij multivariate OLS-regressie gebruikt, met als afhankelijke variabelen tijd met kinderen 's middags en tijd met kinderen 's avonds. Onderzoek van Stewart (2013) laat zien dat OLS een accurate manier is om tijdsbestedingsdata te analyseren. In de eerste stap van ons model zijn de dummyvariabelen voor werk buiten kantoortijden en parttime werk toegevoegd, samen met de controlevariabelen. Dit gedeelte van de analyses maakt het mogelijk om Basishypothese $1 \mathrm{a}$ en $1 \mathrm{~b}$ te toetsen, evenals Hypothese 2. In de tweede stap hebben we gekeken naar de interactie tussen werk buiten kantoortijden en parttime werk. Hiervoor zijn vier groepen aangemaakt, namelijk parttime werk binnen kantoortijden, fulltime werk binnen kantoortijden, parttime werk buiten kantoortijden en fulltime werk buiten kantoortijden. Om de interpretatie van de resultaten te vergemakkelijken hebben we de analyses met twee verschillende referentiegroepen uitgevoerd, namelijk parttime werk binnen kantoortijden en parttime werk buiten kantoortijden. Met deze analyses worden Hypothese 3 tot en met 6 getoetst. De analyses zijn uitgevoerd met gebruik van SPSS versie 20.

\section{Resultaten}

Beschrijvende analyses

In tabel 1 staan de beschrijvende statistieken van de afhankelijke, onafhankelijke en controlevariabelen.

Uit tabel 1 blijkt dat respondenten gemiddeld iets meer dan een uur met hun kinderen doorbrengen tussen 14 uur en 18 uur. Voor de avond is dit getal beduidend hoger, ouders brengen dan ongeveer 2,5 uur door met hun kinderen. Hoewel de 
tijd besteed met kinderen lager is dan blijkt uit het Nederlandse tijdsbestedingsonderzoek (Cloïn et al., 2013), komt dit waarschijnlijk doordat het huidige onderzoek zich alleen richt op doordeweekse dagen. Wat betreft het werkschema van de ouders blijkt ongeveer één vijfde van de respondenten buiten kantoortijden te werken, dit getal is iets lager dan andere recente Nederlandse data laten zien (Verhoef et al., 2015). Een ruime meerderheid (74\%) van de respondenten werkt minder dan 35 uur per week, wat deels te verklaren is door de aard van het onderzoek. Respondenten worden namelijk gevraagd om voor een specifieke week het dagboek in te vullen, waarbij vakanties niet worden uitgesloten. Eerder onderzoek laat overigens vergelijkbare cijfers zien voor parttime werk onder ouders met jonge kinderen (Verhoef et al., 2015). De respondenten zijn relatief hoog opgeleid vergeleken met de algemene Nederlandse bevolking (Centraal Bureau voor de Statistiek, 2015). Tabel 1 laat verder zien dat iets meer dan de helft van de steekproef vrouw is, respondenten meestal één of twee kinderen hebben en bijna de helft een kind heeft tussen de 0 en 3 jaar oud. Ten slotte zitten er in de steekproef iets meer respondenten die in 2006 hebben deelgenomen aan het TBO, vergeleken met 2011.

Voordat we naar de resultaten van verklarende analyses gaan, staan in figuur 1 eerst de verschillende werkschemacombinaties afgezet tegen de ouder-kindtijd in de middag.

Figuur 1 suggereert dat ouder-kindtijd in de middag voornamelijk samenhangt met het aantal werkuren van ouders, niet met hun werkschema. De verschillen tussen parttime werkende ouders die binnen of buiten kantoortijden werken zijn namelijk minimaal, net zoals voor fulltime werkende ouders die binnen of buiten kantoortijden werken. Voor ouder-kindtijd in de avond, weergegeven in Figuur 2, ziet het beeld er iets anders uit. Deze figuur laat namelijk zien dat de tijd die ouders met hun kinderen doorbrengen in de avond lager is als ouders buiten kantoortijden werken, ongeacht het aantal werkuren. Wel brengen parttime werkende ouders wederom meer tijd met hun kinderen door dan fulltime werkende ouders. 


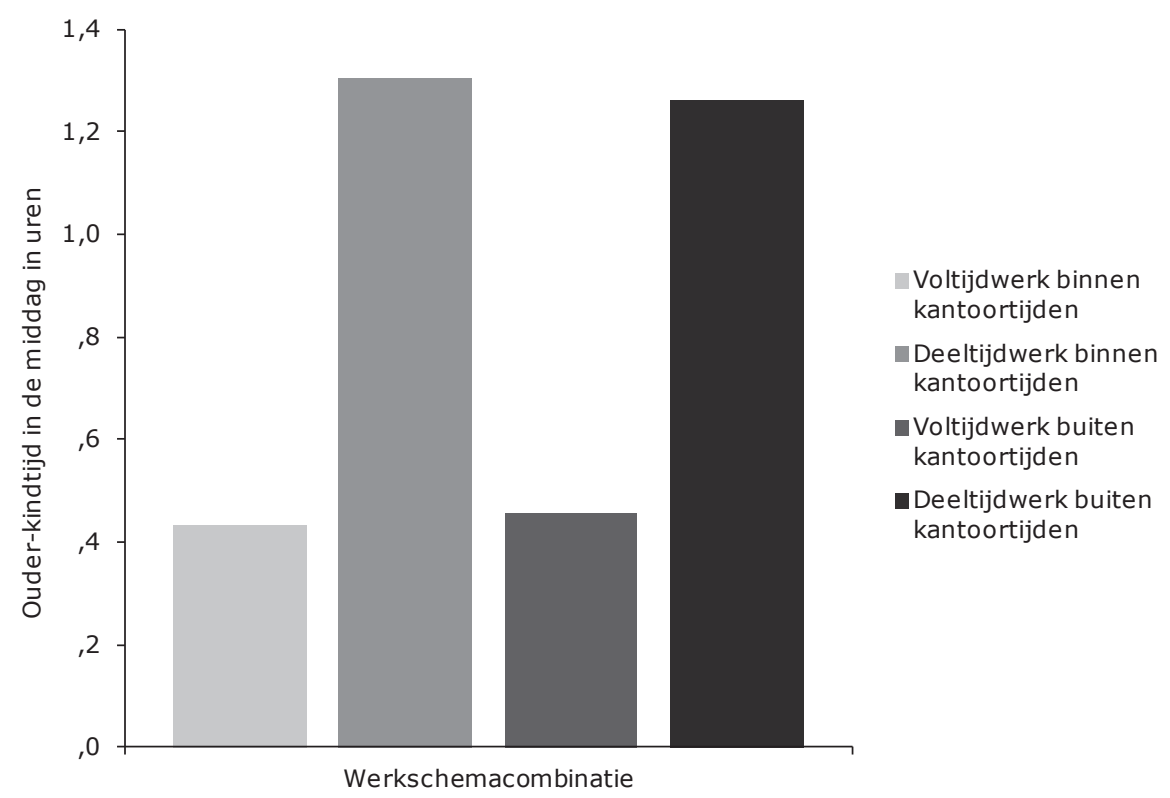

Figuur 1 Staafdiagram van de ouder-kindtijd in de middag voor verschillende werkschemacombinaties.

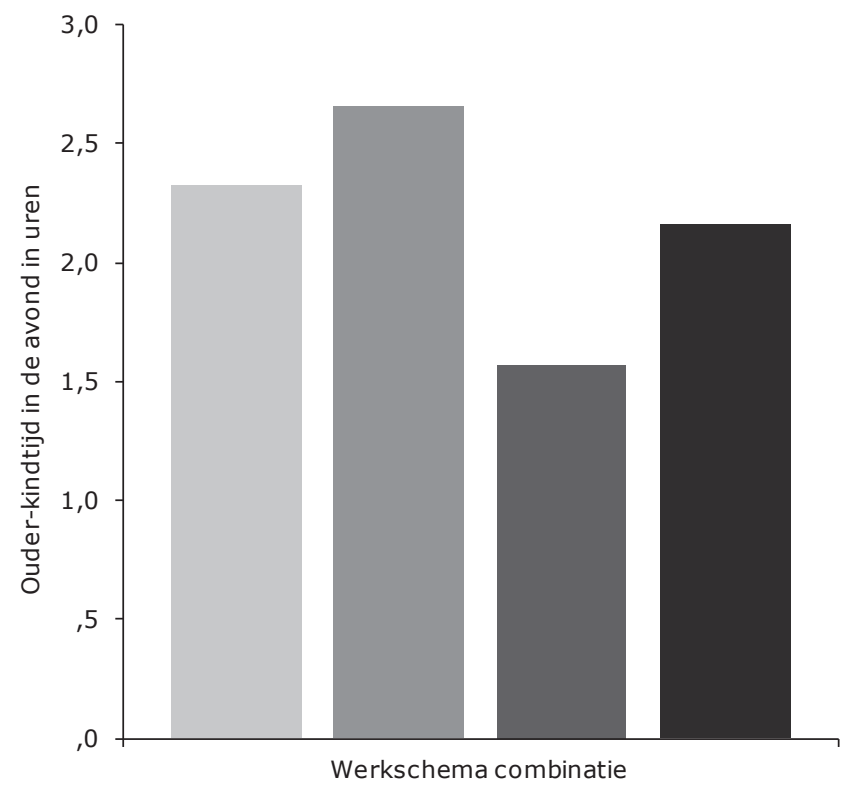

Voltijd werk binnen kantoortijden

Deeltijd werk binnen kantoortijden

- Voltijd werk buiten kantoortijden

- Deeltijd werk buiten kantoortijden

Figuur 2 Staafdiagram van de ouder-kindtijd in de avond voor verschillende werkschema combinaties. 


\section{Verklarende analyses}

In tabel 2 staan de resultaten van de verklarende analyses betreffende tijd met kinderen 's middags en 's avonds. Uit Model 1a blijkt dat de tijd die ouders tussen 14 en 18 uur doorbrengen samenhangt met of ouders parttime werken $(b=0,45$, $p<, 001)$. Meer specifiek laat dit model zien dat ouders die minder dan 35 uur per week werken 's middags 27 minuten meer ouder-kindtijd doorbrengen dan ouders die fulltime werken. Er was geen significante samenhang tussen ouderkindtijd 's middags en werk buiten kantoortijden. Basishypothese 1a wordt daarom niet ondersteund. Verder blijken vrouwelijke respondenten meer tijd met hun kinderen door te brengen $(b=0,75, p<, 001)$, evenals respondenten met een kind tussen de 0 en 3 jaar oud $(b=0,81, p<, 001)$.

Voor ouder-kindtijd tussen 18 en 22 uur zien de resultaten er wat anders uit (Model 1b). Niet parttime werk, maar werk buiten kantoortijden hangt hier samen met de ouder-kindtijd. Respondenten die buiten kantoortijden werken brengen 's avonds significant minder tijd door met hun kinderen $(b=-0,60, p<$, 001). Dit houdt in dat ouders die voornamelijk 's avonds of 's nachts werken tussen 18 en 22 uur 36 minuten minder ouder-kindtijd doorbrengen dan ouders die binnen kantoortijden werken. Met dit resultaat wordt Basishypothese $1 \mathrm{~b}$ ondersteund. Vrouwelijke respondenten $(b=0,70, p<, 001)$ en respondenten met een hogere opleiding $(b=0,25, p=, 003)$, meer kinderen $(b=0,26, p=, 001)$ en een kind tussen de 0 en 3 jaar oud ( $b=1,12, p<, 001)$ brengen 's avonds juist meer tijd door met hun kinderen. Ook blijken respondenten uit 2011 meer tijd met hun kinderen door te brengen dan respondenten uit $2006(b=0,30, p=, 015)$.

Met Hypothese 2 stelden wij dat de positieve samenhang van werk buiten kantoortijden met ouder-kindtijd in de middag zwakker zou zijn dan de positieve samenhang van werk binnen kantoortijden met ouder-kindtijd in de avond. De resultaten zijn in lijn met deze hypothese. Immers, ouders die buiten kantoortijdtijden werken, brengen 's middags niet meer (of minder) tijd met hun kinderen door terwijl ouders die binnen kantoortijden werken 's avond wel meer ouderkindtijd rapporteren.

Om onze verdere hypothesen te kunnen toetsen hebben we in de volgende stap van de analyses gekeken naar de interactie tussen werk buiten kantoortijden en parttime werk, door vier groepen te onderscheiden. Modellen 2a en $2 b$ geven de resultaten weer van deze analyse met als referentiegroep parttime werk buiten kantoortijden; in Modellen 3a en 3b vormt parttime werk binnen kantoortijden de referentiegroep. De modellen zijn verder identiek. 


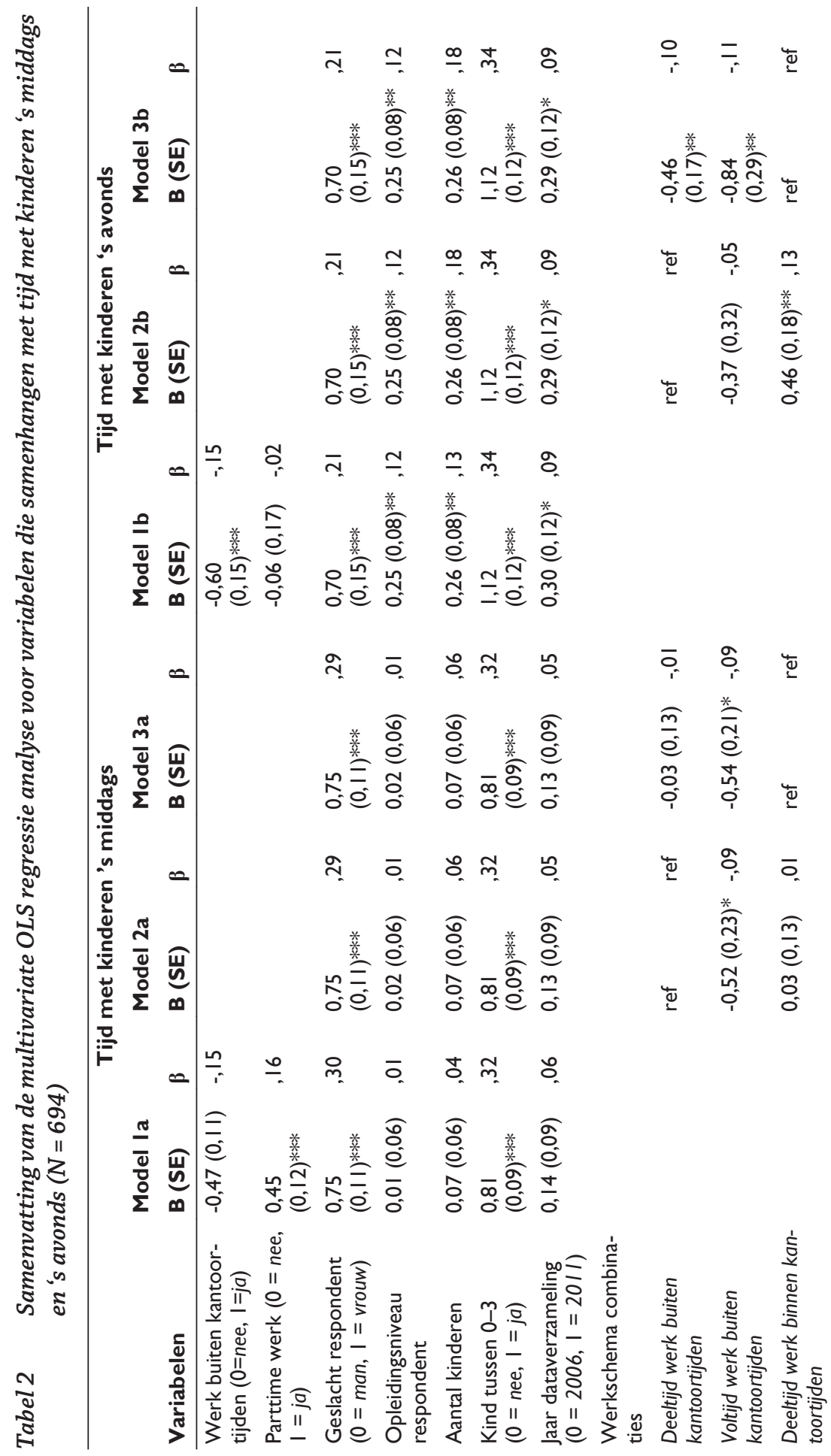




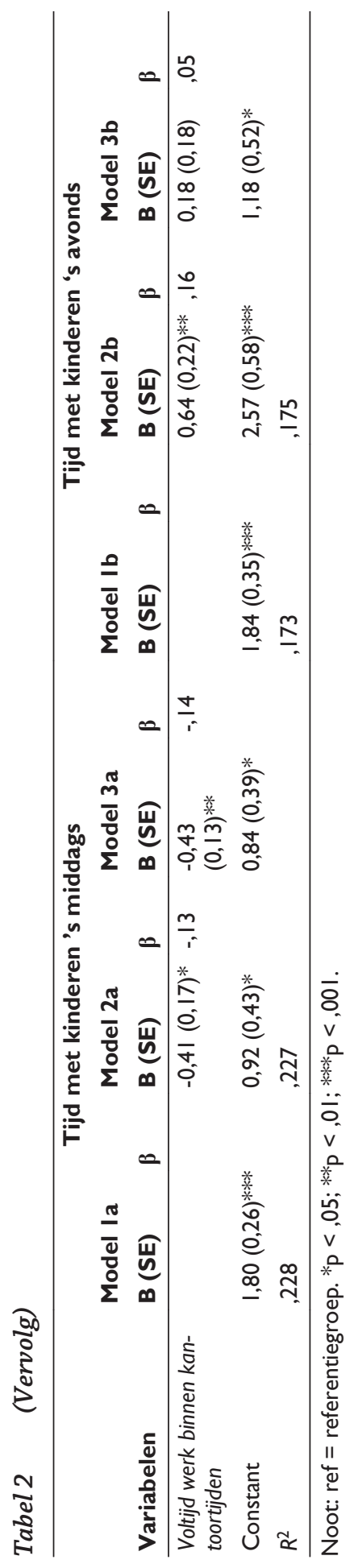


De resultaten van Model 2a maken het mogelijk om ouder-kindtijd in de middag te vergelijken binnen de groep ouders die buiten kantoortijden werkt. Hieruit blijkt dat ouders die fulltime buiten kantoortijden werken 's middags minder tijd met hun kinderen doorbrengen dan ouders die parttime buiten kantoortijden werken $(b=-0,52, p=, 027)$. Met deze resultaten wordt Hypothese 3 ondersteund; de samenhang is immers positiever voor ouders met een parttime baan buiten kantoortijden. Ook ouders met fulltime werk binnen kantoortijden blijken minder tijd in de middag met hun kinderen door te brengen dan ouders met een parttime baan buiten kantoortijden $(b=-0,41, p=, 014)$.

Wanneer we binnen de groep ouders die buiten kantoortijden werkt naar de verschillen in ouder-kindtijd in de avond kijken (Model 2b), blijkt er geen significant verschil te zijn tussen ouders met een parttime of fulltime baan. Hypothese 5 wordt daarom niet ondersteund. Het is wel zo dat deze groep ouders (die buiten kantoortijden werkt), 's avonds minder tijd met hun kinderen doorbrengt. Dit geldt zowel voor ouders die parttime werken $(b=0,46, p=, 007)$ als voor ouders die fulltime werken $(b=0,64, p=, 004)$. De resultaten voor de controlevariabelen zijn vergelijkbaar met Model 1, die hierboven beschreven staan.

Tenslotte kijken we naar Model 3a en 3b, waar ouders met een parttime baan binnen kantoortijden de referentiegroep vormen. Model 3a laat zien dat ouders met een fulltime baan binnen kantoortijden 's middags significant minder tijd met hun kinderen doorbrengen dan ouders met parttime werk binnen kantoortijden ( $b=-0,43, p=, 001)$. Hiermee wordt Hypothese 4 ondersteund, de samenhang is namelijk negatiever voor ouders met een fulltime baan binnen kantoortijden. Ook blijken ouders met een fulltime baan buiten kantoortijden 's middags minder tijd met hun kinderen door te brengen dan ouders met een parttime baan buiten kantoortijden $(b=-0,54, p=, 011)$.

Wat betreft de ouder-kindtijd in de avond (Model 3b) is er geen significant verschil binnen de groep ouders die binnen kantoortijden werken, waardoor er geen ondersteuning is voor Hypothese 6. Ouders die buiten kantoortijden werken, zowel parttime ( $b=-0,46, p=, 007)$ als fulltime $(b=-0,84, p=, 004)$, brengen 's avonds wel minder tijd door met hun kinderen dan ouders die parttime binnen kantoortijden werken. De resultaten voor de controlevariabelen zijn wederom vergelijkbaar met Model 1.

Samenvattend laten onze resultaten zien dat ouder-kindtijd in de middag voornamelijk afhangt van het aantal werkuren van ouders, terwijl het werkschema juist van belang is voor de ouder-kindtijd in de avond. Zowel de werkuren als het werkschema zijn dus van belang, afhankelijk van het moment op de dag. De werkuren en het werkschema interacteren dus niet.

\section{Aanvullende analyses}

Aangezien de literatuur heeft laten zien dat vrouwen meer gemotiveerd zijn om werkgerelateerde hulpbronnen te gebruiken voor familiedoeleinden (e.g., Bielby, 1992; Lesnard, 2008; Roeters, Van der Lippe \& Kluwer, 2010) hebben we aanvul- 
lende analyses uitgevoerd met betrekking tot het geslacht van de ouder. Hiermee hebben we de effecten vergeleken tussen mannen en vrouwen. Voor vaders kwamen de resultaten overeen met tabel 2, terwijl voor moeder een aantal resultaten niet significant waren. Dit valt te verklaren door een gebrek aan variatie binnen de moeders, aangezien de overgrote meerderheid van de vrouwen in onze steekproef $(95,64 \%)$ namelijk parttime werkt. Hierdoor waren zowel het hoofdeffect als de werkschemacombinaties met parttime werk niet significant.

\section{Conclusie}

In deze studie hebben we de samenhang tussen de werktijden van ouders en ouder-kindtijd in de middag en de avond onderzocht, waarbij we qua werktijden zowel hebben gekeken naar het aantal werkuren als het werkschema van ouders. Waar eerder onderzoek zich met name heeft gericht op de totale tijd met kinderen hebben wij onderscheid gemaakt tussen twee tijdvakken: van 14 tot 18 uur en van 18 tot 22 uur.

Onze studie sluit aan bij het huidige debat rondom de '24/7'-maatschappij en de gevolgen hiervan voor het gezinsleven. Waar de pessimisten binnen dit debat vooral beperkingen zien voor ouder-kindtijd wanneer ouders buiten kantoortijden werken, stellen de optimisten juist dat werk buiten kantoortijden gezinnen in staat stelt om meer tijd samen door te brengen. Hoewel onze resultaten wat betreft ouder-kindtijd in de middag geen duidelijk beeld laten zien, lijken de resultaten voor ouder-kindtijd in de avond aan te sluiten bij de pessimistische visie binnen het debat.

Onze resultaten bouwen voort op de studie van Täht en Mills (2012) en presenteren een interessante puzzel: waar Täht en Mills vinden dat ouders met werk buiten kantoortijden meer activiteiten ondernemen met hun kinderen, laten onze resultaten zien dat deze ouders 's middags evenveel en 's avonds minder ouderkindtijd doorbrengen, vergeleken met ouders die binnen kantooruren werken. Het is mogelijk dat ouders die buiten kantoortijden werken meer kortdurende activiteiten met hun kinderen ondernemen, maar er is nieuw onderzoek nodig om hier meer inzicht in te krijgen. Voor nu lijken onze resultaten in ieder geval meer aan te sluiten bij het standpunt van de pessimisten, gezien de bevinding dat ouders die buiten kantoortijden werken 's avonds minder tijd met hun kinderen doorbrengen.

Binnen de groep ouders die buiten kantoortijden werkt blijkt het aantal werkuren samen te hangen met de ouder-kind in de middag. Ouders met een fulltime baan buiten kantoortijden brengen namelijk minder tijd door met hun kinderen dan ouders die parttime buiten kantoortijden werken. Voor ouder-kindtijd in de avond waren er geen verschillen binnen deze groep. Voor ouders die binnen kantoortijden werken laat onze studie hetzelfde beeld zien. Deze bevindingen zijn niet onverwacht; afhankelijk van hun werkschema zullen fulltime werkende 
ouders ofwel op hun werk zijn ofwel aan het bijslapen of druk met andere activiteiten zijn.

Het is echter wel verrassend dat eenzelfde samenhang met ouder-kindtijd in de avonden niet werd gevonden. Blijkbaar lukt het ouders met een fulltime baan binnen kantoortijden om hun andere activiteiten om de ouder-kindtijd heen te plannen; er blijkt geen sprake te zijn van verdringing van de tijd met kinderen als ouders meer uren werken binnen kantoortijden. Eerdere literatuur heeft dan ook laten zien dat ouders de tijd met hun kinderen beschermen (e.g., Bianchi, 2000). Waarom alleen ouders met werk binnen kantoortijden hierin lijken te slagen vormt een interessant vraagstuk. Wellicht komt dit door de extra mentale en fysieke inspanning waar werk buiten kantoortijden om vraagt (e.g., Jamal, 2004; Schulz et al., 2004; Perry-Jenkins et al., 2007), wat het voor ouders lastiger kan maken om met concurrerende activiteiten om te gaan. Een soortgelijke redenering kan opgaan voor de bevinding dat ouders met parttime werk binnen kantoortijden in de middag wel meer tijd met hun kinderen doorbrengen dan fulltime werkende ouders, terwijl ouders met parttime werk buiten kantoortijden dit in de avond niet doen. Het is daarom van belang om meer inzicht te krijgen in de extra belasting die werk buiten kantoortijden van ouders vraagt, om deze ouders handvatten te kunnen bieden voor de omgang met concurrerende activiteiten buiten hun werk.

Een andere interessante insteek voor vervolgonderzoek is het onderzoeken van week-weekendverschillen. Het is namelijk mogelijk dat ouders met een fulltime baan binnen of buiten kantoortijden de tijd die zij gedurende de week niet aan hun kinderen kunnen besteden in het weekend inhalen. In het weekend zullen kinderen meer beschikbaar zijn, net zoals hun ouders, aangezien er meer variatie is in werktijden buiten kantoortijden. Het zou daarom waardevol zijn voor dit onderzoeksveld om de samenhang tussen de werktijden van ouders en ouderkindtijd in de week en in het weekend te contrasteren. In plaats van de kwantitatieve ouder-kindtijd kan vervolgonderzoek zich ook richten op de soort activiteiten die ouders en kinderen samen doen. Aangezien vooral interactieve activiteiten een positief effect hebben op het welzijn van kinderen (Hsin \& Felfe, 2014; Milkie, Nomaguchi \& Denny, 2015), is het relevant om te onderzoeken in hoeverre de werktijden van ouders samenhangen met zogenoemde 'quality time'.

Ondanks het feit dat de resultaten van de huidige studie interessante aanknopingspunten hebben voortgebracht voor vervolgonderzoek is er een aantal beperkingen die genoemd moeten worden. Om een voldoende grote steekproef te genereren hebben wij namelijk data uit 2006 en 2011 met elkaar gecombineerd. Gedurende deze tijdsperiode hebben er grote veranderingen plaatsgevonden in de kinderopvangsector (Jongen, 2008), waardoor het mogelijk is dat ouders uit 2011 om een andere reden buiten kantoortijden werken dan ouders uit 2006. Door te controleren voor het jaar van dataverzameling hebben wij geprobeerd hier rekening mee te houden, maar idealiter zou men met een steekproef uit één bepaald jaar willen werken om dergelijke invloeden uit te sluiten. Verder hebben wij geen onderscheid kunnen maken binnen de groep ouders die buiten kantoortijden 
werkt. Eerder onderzoek heeft echter geconstateerd dat er variatie is in de gevolgen van werk buiten kantoortijden (e.g., Presser, 2003). Zo blijkt nachtwerk namelijk de meest negatieve gevolgen te hebben voor het familieleven. Het is daarom mogelijk dat de samenhang tussen werk buiten kantoortijden en ouderkindtijd niet zo eenduidig is als onze studie laat zien. Echter, vanwege te kleine subgroepen in de data was het niet mogelijk om deze verschillen te onderzoeken. Ten slotte hebben wij ons enkel gericht op ouders die in de dagboekweek gewerkt hebben en op basis hiervan een indeling in fulltime/parttime gemaakt. We weten echter niet waarom mensen parttime werken. Het kan bijvoorbeeld zo zijn dat ouders deels met ouderschapsverlof zijn en hierdoor meer tijd met hun kinderen doorbrengen. Meer inzicht in de samenstelling van de werkuren van ouders is daarom wenselijk.

De waarde van dit onderzoek ligt in het gebruik van tijdsbestedingsdata, aangezien dit ons in staat heeft gesteld objectief de timing van het werk van ouders te bepalen. Ook geven de data gedetailleerde informatie over ouder-kindtijd en door de manier van dataverzameling is het geven van sociaal wenselijke antwoorden beperkt. De resultaten laten zien dat de aanname dat ouders die buiten kantoortijden werken minder tijd met hun kinderen doorbrengen deels correct is; voor de avonduren is dit inderdaad het geval. In hoeverre dit echter problematisch is voor kinderen valt te bezien, aangezien ander onderzoek laat zien dat deze ouders wel meer activiteiten met hun kinderen ondernemen (Täht \& Mills, 2012). De arbeidsduur van ouders was met name van belang voor de middaguren, aangezien parttime werkende ouders dan meer tijd met hun kinderen doorbrengen. Deze bevindingen onderstrepen het belang om in te zoomen op de totale tijd die ouders met hun kinderen doorbrengen, aangezien tijd in de middag en tijd in de avond samenhangen met verschillende werkfactoren.

\section{Literatuur}

Bianchi, S.M. (2000). Maternal employment and time with children: Dramatic change or surprising continuity? Demography, 37, 401-414.

Bianchi, S.M., Robinson, J.P. \& Milkie, M.A. (2006). Changing rhythms of American family life. New York: Russell Sage Foundation.

Bielby, D.D. (1992). Commitment to work and family. Annual Review of Sociology, 18, 281-302.

Centraal Bureau voor de Statistiek. (2015). Bevolking; hoogst behaald onderwijsniveau; geslacht, leeftijd en herkomst. Verkregen via http://statline.cbs.nl.

Cloïn, M., Schols, M., Broek, A. van den \& Koutamanis, M. (2010). Tijd op orde? Een analyse van de tijdsorde vanuit het perspectief van de burger. Den Haag: Sociaal en Cultureel Planbureau.

Cloïn, J.C.M., Broek, A. van den, Dool, R. van den, Haan, J., Hart, J.J.M., Houwelingen, P. \& Spit, J.S. (2013). Met het oog op de tijd: Een blik op de tijdsbesteding van Nederlanders. Den Haag: Sociaal en Cultureel Planbureau.

Connelly, R. \& Kimmel, J. (2007). The role of non-standard work hours in maternal caregiving for young children. IZA Discussion Papers, No. 3093. 
Coyette, C., Fiasse, I., Johansson, A., Montaigne, F. \& Strandell, H. (Eds.) (2015). Being young in Europe today. Luxembourg: Publications Office of the European Union.

Han, W.J. (2004). Nonstandard work schedules and child care decisions: Evidence from the NICHD Study of Early Child Care. Early Childhood Research Quarterly, 19, 231-256.

Heymann, S.J. \& Earle, A. (2001). The impact of parental working conditions on schoolage children: The case of evening work. Community, Work and Family, 4, 305-325.

Hofferth, S.L. \& Sandberg, J.F. (2001). How American children spend their time. Journal of Marriage and Family, 63, 295-308

Hsin, A. \& Felfe, C. (2014). When does time matter? Maternal employment, children's time with parents, and child development. Demography, 51, 1867-1894.

Jamal, M. (2004). Burnout, stress and health of employees on non-standard work schedules: A study of Canadian workers. Stress and Health, 20, 113-119.

Kamphuis, C., Dool, R. van den, Broek, A. van den, Stoop, I., Adelaar, P. \& Haan, J. de (2009). TBO/eu en TBO/nl. Den Haag: Sociaal en Cultureel Planbureau.

Kan, M.Y. \& Pudney, S. (2008). Measurement error in stylized and diary data on time use. Sociological Methodology, 38, 101-132.

La Valle, I., Arthur, S., Millward, C., Scott, J. \& Clayden, M. (2002). Happy families? Atypical work and its influence on family life. Bristol, UK: The Policy Press.

Lesnard, L. (2008). Off-scheduling within dual-earner couples: An unequal and negative externality for family time. American Journal of Sociology, 114, 447-490.

Li, J., Johnson, S.E., Han, W.J., Andrews, S., Kendall, G., Strazdins, L. \& Dockery, A. (2014). Parents' nonstandard work schedules and child well-being: A critical review of the literature. Journal of Primary Prevention, 35, 53-73.

Jongen, E. (2008). Kinderopvang: waarheen, waarvoor? TPEdigitaal, 2, 27-48.

Milkie, M.A., Mattingly, M.J., Nomaguchi, K.M., Bianchi, S.M. \& Robinson, J.P. (2004). The time squeeze: Parental statuses and feelings about time with children. Journal of Marriage and Family, 66, 739-761.

Milkie, M.A., Nomaguchi, K.M. \& Denny, K.E. (2015). Does the amount of time mothers spend with children or adolescents matter? Journal of Marriage and Family, 77, 355-372.

Monna, B. \& Gauthier, A.H. (2008). A review of the literature on the social and economic determinants of parental time. Journal of Family and Economic Issues, 29, 634-653.

Nock, S.L. \& Kingston, P.W. (1988). Time with children: The impact of couples' work-time commitments. Social Forces, 67, 59-85.

OECD Data Base. (2013). Incidence of part-time employment. http://doi.org/10.1787/ factbook-2013-table139-en.

Perry-Jenkins, M., Goldberg, A.E., Pierce, C.P. \& Sayer, A.G. (2007). Shift work, role overload, and the transition to parenthood. Journal of Marriage and Family, 69, 123-138.

Portegijs, W., Cloïn, M. \& Merens, A. (2014). Krimp in de kinderopvang. Den Haag: Sociaal en Cultureel Planbureau.

Presser, H.B. (2003). Working in a 24/7 economy: Challenges for American families. New York: Russell Sage Foundation.

Presser, H.B., Gornick, J.C. \& Parashar, S. (2008). Gender and nonstandard work hours in 12 European countries. Monthly Labor Review, 131, 83-103.

Roeters, A., Lippe, T. van der \& Kluwer, E.S. (2010). Work characteristics and parent-child relationship quality: The mediating role of temporal involvement. Journal of Marriage and Family, 72, 1317-1328.

Schulz, M.S., Cowan, P.A., Pape Cowan, C. \& Brennan, R.T. (2004). Coming home upset: Gender, marital satisfaction, and the daily spillover of workday experience into couple interactions. Journal of Family Psychology, 18, 250-263. 
Stewart, J. (2013). Tobit or not Tobit? Journal of Economic and Social Measurement, 3, 263-290.

Strazdins, L., Korda, R.J., Lim, L.L., Broom, D.H. \& D’Souza, R.M. (2004). Around-theclock: Parent work schedules and children's well-being in a 24-h economy. Social Science \& Medicine, 59, 1517-1527.

Täht, K. \& Mills, M.C. (2012). Nonstandard work schedules, couple desynchronization and parent-child interaction: A mixed-method analysis. Journal of Family Issues, 33, 1054-1087.

Verhoef, M., Tammelin, M., May, V., Rönkä, A. \& Roeters, A. (2015). Childcare and parental work schedules: A comparison of childcare arrangements among Finnish, British and Dutch dual-earner families. Community, Work and Family. Advance online publication.

Wight, V.R., Raley, S.B. \& Bianchi, S.M. (2008). Time for children, one's spouse and oneself among parents who work non-standard hours. Social Forces, 87, 243-271.

Zick, C.D., Bryant, W.K. \& Osterbacka, E. (2001). Mothers' employment, parental involvement, and the implications for intermediate child outcomes. Social Science Research, 30, 25-49. 